10.2478/aucft-2019-0018

\title{
CHEMICAL AND SENSORY PROPERTIES OF PROBIOTICATED DRINKS FROM BLENDS OF AFRICAN YAM BEAN, SOYBEAN AND COCONUT MILK ANALOGUES
}

\author{
- Research paper -
}

\author{
Abiodun Victor IKUJENLOLA ${ }^{1}$, Esther Abiodun ADUROTOYE, Hezekiah Adekanmi ADENIRAN \\ Department of Food Science and Technology, Obafemi Awolowo University Ile-Ife, Nigeria.
}

\begin{abstract}
This study assessed the physicochemical and sensory properties of 'probiotic' drink from blends of milk analogues from African yam bean, soybean and coconut. Milk analogues were blended at ratios of 1:1:1, 3:1:1 and 5:1:1 (African yam bean: soybean: coconut ) as samples A, B and C respectively. These samples were fermented for $24 \mathrm{~h}$ at $43^{\circ} \mathrm{C}$ using Lactobacillus delbrueckii. The results showed that the fermented milk analogue of ratio 1:1:1 was the most acceptable in terms of sensory parameters. The $\mathrm{pH}$ of the milk analogues ranged from 5.07 to 5.85. The sample B1 (fermented (1:1:1) African yam bean: soybean: coconut) had a crude protein of $2.38 \%$, potassium of $80.13 \mathrm{mg} / 100 \mathrm{~g}$, phytate of $2.85 \mathrm{mg} / 100 \mathrm{~g}$ and saponin was $0.19 \mathrm{mg} / 100 \mathrm{~g}$. The study concluded that the sample with equal ratio of African yam bean, soybean and coconut adjudged the most acceptable by tasters.
\end{abstract}

Keywords: kunun zaki; milk analogues; phytate; reducing sugar

\section{INTRODUCTION}

Most probiotic foods in markets today are dairy based. The choice and preference of consumers tend towards foods that are supplemented with or replaced by plants. This is because plants have a minimal cholesterol contents and may serve as a relief for consumers who suffer from lactose intolerance. The increasing awareness of the interaction between diet and health has led to a high acceptance and craving for food and food products that boost health with respect to providing basic nutrients. This awareness has prompted market demand particularly within children and other highrisk individuals for functional products containing probiotic bacteria. These have positive effect(s) on health and it is of consumers' interest and attention. This is being promoted by health professionals (Yilmaz-Ersan and Kurdal, 2014).

The term 'probiotics' originates from the Greek 'Pro bios' meaning 'for life' used to describe microorganisms that are responsible for the beneficial effects for humans and animals (Aguolar and Rovera (2019).

These microorganisms contribute to intestinal microbial balance and contribute to maintaining sound health (Soccol et al., 2010). These beneficial microorganisms are majorly strains of the genera

Received: 04.07.2019.

Accepted in revised form: 9.12.2019

${ }^{1}$ Corresponding author. E-Mail address: avjenlola@gmail.com
Lactobacillus and Bifidobacterium, likewise strains of Bacillus, Pediococcus, and some yeast also perform these functions. All display a function in the protection of the organism against pathogens and also strengthen the host's immune system (Soccol et al., 2010). Probiotics perform a key function in accelerating host immunity to colonization by exogenous, potentially pathogenic organisms. This is possible through different mechanisms such as production of lactic acid, hydrogen peroxide or acetic acid which accelerate the acidity of the intestine and stops the reproduction of pathogens (Hassan et al., 2013). Probiotics can be presented in dairy and non-dairy products. Fermented dairy foods are the perfect conveyors for probiotics, which promote growth and enhance the thriving of these organisms. Of these foods, yoghurt is the most popular, and provides higher contents of protein, carbohydrate, certain B vitamins and calcium than milk (YilmazErsan and Kurdal, 2014). However, non- dairy fermented foods have also been produced mostly from underutilized and under-exploited plants (Madhavi et al., 2018). Adeniran et al. (2015) produced a probiotic drink from milk blends of African yam bean soybean and coconut and assessed how viable the probiotic organisms in vitro. Osundahunsi et al. (2007) also determined the quality and consumer acceptability of soy-yoghurt with different colours and fruit flavours. 
Ebhodaghe et al. (2012) determined the viability, physico-chemical characteristics and inhibitory effect of Bifidobacteria in soymilk. These studies were limited to nutritional and effects of these probiotic drinks in vitro. Mbaeyi (2011) also produced a non-dairy probiotic yoghurt analogue from milk blends of soybean and 'acha' and determined the proximate and micronutrient composition. However, there is scanty information on the nutritional quality of the combination of African Yam Bean, soybean and coconut milk used as a probiotic drink. Therefore, this study is designed to produce and evaluate the chemical and sensory characteristics of probioticated drinks based on the combination of the underutilized crops of African Yam Bean, soybean and coconut.

\section{MATERIALS AND METHODS}

\section{Materials}

The dried seeds of African Yam Bean (AYB), soybean and coconut drupes were collected from IAR\&T, Apata, Ibadan, Nigeria. Lactobacillus delbrueckii characterized and identified from kununzaki drink made in the Department of Food Science and Technology, OAU, Ile-Ife, Nigeria was used as the probiotic organism. The chemicals used were of analytical grade and were supplied by Sigma Adrich, USA.

\section{Preparation of the vegetable extracts}

Milk extracts from the plant sources were obtained using the following procedures.(Figure 1):

\section{Preparation of AYB milk analogue}

Seeds were examined and sorted to remove extraneous materials such as dirt, dust as well as shriveled and diseased (pest infested ones). The seeds were washed, steeped in warm water for 7 hours, drained the water and blanched for 5 mins at $100{ }^{\circ} \mathrm{C}$, dehulled and milled with water $(1: 4)$ in a blender (Marlex, Excella model, India). The resulting slurry was filtered, allowed to stand for 5 mins and then boiled for 15 mins with constant stirring and rapid cooling (Aminigo et al., 2007).

\section{Production of soymilk}

Wholesome soybean seeds were steeped in warm water for 6 hours to ensure a bean:water ratio of 1:3. The seeds were drained, rinsed with water and blanched for 5 mins at $100{ }^{\circ} \mathrm{C}$, dehulled and milled with water. The slurry was filtered using a muslin cloth and the extract was boiled for 15 mins with constant stirring and rapid cooling (Udeozor, 2012).

\section{Production of coconut milk}

The seed coat of the coconut flesh (solid part) was scraped off and cut into small pieces to enhance milling, blended with water in the ratio $2: 1$. The extracted solution was heated at $90{ }^{\circ} \mathrm{C}$ for 10 mins and stored in a refrigerator for $2 \mathrm{~h}$ at $0{ }^{\circ} \mathrm{C}$. Coconut fat was scooped from the surface of the mixture. Coconut milk was homogenized with coconut water for 2 mins before use (Sanful, 2009).

\section{Formulation of milk blends}

Blends of milks from african yam bean, coconut and soybean were obtained with proportions of 1:1:1 (33.33\% AYBM: 33.33\% CM: 33.33\% SM), 3:1:1 (60\% AYBM: $20 \%$ CM: 20\% SM) and 5:1:1 (71.43\% AYBM: $14.29 \%$ CM: $14.29 \% \quad$ SM), respectively. The milk samples were homogenised in a blender (Marlex, Excella model, India) for 2 mins before use.

\section{Selected milk analogues blends fermented with probiotic strains}

The milk blends were sterilized for $15 \mathrm{~min}$ at $85^{\circ} \mathrm{C}$ and later cooled to $45{ }^{\circ} \mathrm{C}$ in a water bath. Lactobacillus delbrueckii isolate was reconstituted in diluted water. The milk blends were fermented with $10 \%(\mathrm{v} / \mathrm{v})$ of probiotic strain and incubated at $45 \pm 1{ }^{\circ} \mathrm{C}$ for 24 hours. The resulting fermented milk samples were kept under refrigeration temperature $\left(4 \pm 1{ }^{\circ} \mathrm{C}\right)$ for an hour to halt fermentation process, it was stirred using a sterile glass rod to break the curd formed, then bottled and stored as required before use (Amakoromo et al., 2012). The culture in MRS agar slope was scraped and thrice with sterile distilled water. The optical density of the suspension which was obtained with a spectrophotometer (Spectrum Lab, 752s UV Spectrophotometer) was adjusted to 0.3 before being used for inoculation. Figure 1 shows the production of milk analogues and fermented milk analogues.

\section{Proximate composition of the samples}

The crude protein, crude fat, crude fibre, ash and moisture content were determined using the method of AOAC (1990; methods 930.10; 978.04; 920.39;954.02; 956.03). Carbohydrate was calculated by difference:

$$
\begin{aligned}
\text { Carbohydrate } & (\%) \\
& =100 \%-(\text { Protein }(\%) \\
& + \text { Moisture }(\%)+\text { Ash }(\%) \\
& + \text { Fat }(\%)+\text { Fibre }(\%))
\end{aligned}
$$

The energy value was calculated using the formula: Energy Value $=($ Protein $\times 4+$ Fat $\times 9+$ Carbohydrate $\times 4) \mathrm{kcal} / 100 \mathrm{~g}$. 


\section{Physicochemical properties}

$\mathrm{pH}$ and Titratable acidity (TTA) were determined using the official method (AOAC, 1990) The methods of Folasade and Oyenike (2012) and Adeniran and Abiose (2011) were used in determining the total solids and total reducing sugars respectively.

\section{Antinutrients determination}

The tannin content was evaluated using the method of Makkar et al., (1993), oxalate content using Oke (1969), saponin by Brunner (1984), phytic acid by Lukas and Markakas (1975).

\section{Mineral analysis}

The mineral content of the flour samples was determined using the official standard method of AOAC (1990). The mineral determined were calcium, iron, zinc, potassium, and sodium.

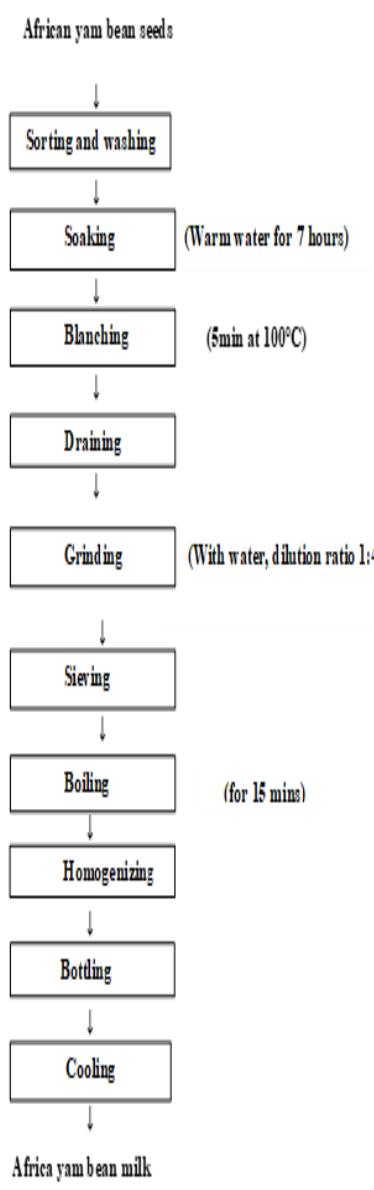

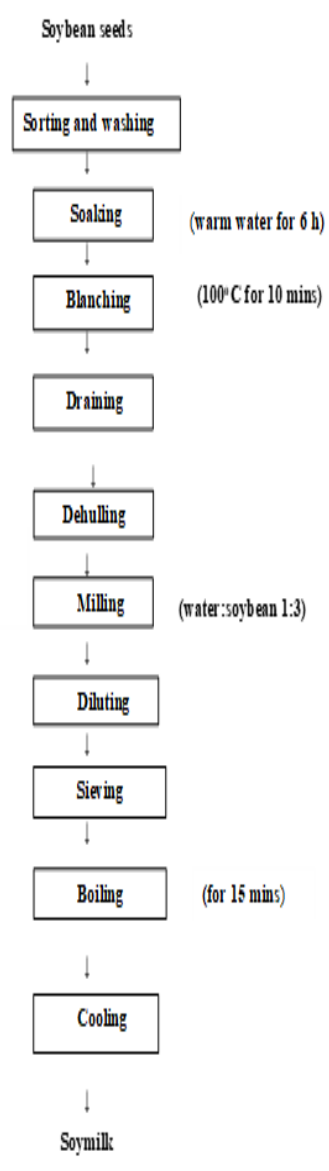

Sensory evaluation of the probioticated samples The sensory qualities of taste, colour, flavor, mouthfeel, and overall acceptability were evaluated by a semi trained 15-member panel using a simple 5point Hedonic scale as described by Larmond (1991) with 1 representing the least score (least preferred) and 5 the highest score (best preferred).

\section{Statistical analysis}

The data obtained from each analysis were means of duplicate readings. The values obtained from proximate, antinutritional, physicochemical, and sensory analyses were subjected to analysis of variance (ANOVA) and the mean was separated by Duncan multiple range test (SPSS, version 20). Significance was determined at 5\% level (Ihekoronye and Ngoddy, 1985)

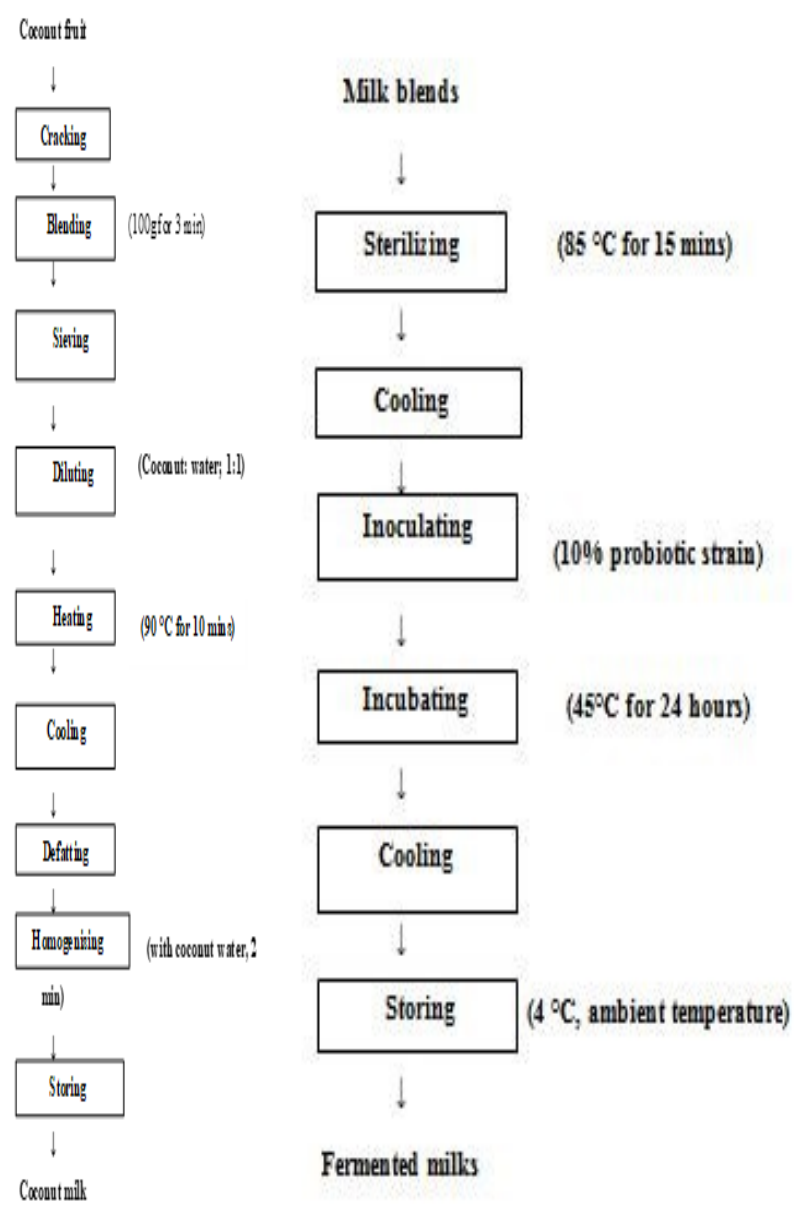

Figure 1. Flow Chart for the production of milk analogues and fermented milk analogues

\section{RESULTS AND DISCUSSION}

Proximate composition of the probioticated drinks

Table 1 shows the results obtained for the analyses of crude protein, crude ash, crude fibre, crude fat, moisture content and carbohydrate content of the yoghurt analogues. The crude protein contents of the analogues ranged from 2.17 to $2.85 \%$ with sample A1 (unfermented 1:1:1) having the lowest and sample B3 (fermented 5:1:1), the highest. The 
protein content increased with an increase in the proportion of AYB and with fermentation. Fermented yoghurt analogues in this study contained higher crude protein than the unfermented samples. This could probably be due to the reduction of the antinutrients by fermentation. Osundahunsi et al. (2007) reported that fermentation improved the protein content in soy milk. However, a reduction in crude protein content with fermentation was reported by Mbaeyi (2011). The crude fat content of the milk analogues was in the range 0.24 to $0.43 \%$ with sample B3 (fermented 5:1:1) having the lowest while sample A1 (unfermented 1:1:1) had the highest. All the values were significantly different at 5\% level. It was observed that the crude fat decreased during fermentation. This may be as a result of breakdown of long chain fatty acids to short chain fatty acids by the probiotic organisms. Similar low fat contents were obtained by Akoma et al. (2005) who produced yoghurt with locally developed starter culture isolated from nunu. Adeniran and Abiose (2011) also reported a high fat content in yoghurt analogues from tigernut, soy and groundnut milk when the proportion of groundnut was high.

Table 1: Proximate Composition of the Milk Analogues samples (\%)

\begin{tabular}{llllllll}
\hline Samples & Protein & Fat & Ash & Fibre & Moisture & Carbohydrate & $\begin{array}{l}\text { Energy } \\
\text { (kcal/100g) }\end{array}$ \\
\hline A1 & $2.17 \pm 0.01^{d}$ & $0.43 \pm 0.00^{\mathrm{a}}$ & $0.97 \pm 0.00^{\mathrm{a}}$ & $0.21 \pm 0.00^{\mathrm{b}}$ & $72.37 \pm 0.03^{\mathrm{b}}$ & $23.85 \pm 0.01^{\mathrm{a}}$ & $107.95^{\mathrm{b}}$ \\
\hline $\mathrm{A} 2$ & $2.27 \pm 0.03^{\mathrm{c}}$ & $0.23 \pm 0.00^{\mathrm{c}}$ & $0.80 \pm 0.00^{\mathrm{b}}$ & $0.17 \pm 0.00^{\mathrm{c}}$ & $71.44 \pm 0.00^{\mathrm{b}}$ & $25.09 \pm 0.03^{\mathrm{a}}$ & $113.91^{\mathrm{a}}$ \\
\hline $\mathrm{A} 3$ & $2.45 \pm 0.01^{\mathrm{b}}$ & $0.34 \pm 0.00^{\mathrm{b}}$ & $0.88 \pm 0.00^{\mathrm{b}}$ & $0.23 \pm 0.00^{\mathrm{b}}$ & $72.57 \pm 0.02^{\mathrm{b}}$ & $23.53 \pm 0.04^{\mathrm{a}}$ & $106.98^{\mathrm{b}}$ \\
\hline $\mathrm{B} 1$ & $2.38 \pm 0.07^{\mathrm{b}}$ & $0.25 \pm 0.00^{\mathrm{c}}$ & $0.89 \pm 0.00^{\mathrm{b}}$ & $0.21 \pm 0.00^{\mathrm{b}}$ & $72.87 \pm 0.02^{\mathrm{b}}$ & $23.40 \pm 0.01^{\mathrm{a}}$ & $105.37^{\mathrm{b}}$ \\
\hline B2 & $2.51 \pm 0.03^{\mathrm{b}}$ & $0.28 \pm 0.00^{\mathrm{c}}$ & $0.98 \pm 0.00^{\mathrm{a}}$ & $0.21 \pm 0.00^{\mathrm{b}}$ & $74.47 \pm 0.03^{\mathrm{b}}$ & $21.55 \pm 0.05^{\mathrm{b}}$ & $98.76^{\mathrm{c}}$ \\
\hline B3 & $2.85 \pm 0.07^{\mathrm{a}}$ & $0.24 \pm 0.00^{\mathrm{c}}$ & $1.05 \pm 0.00^{\mathrm{a}}$ & $0.34 \pm 0.00^{\mathrm{a}}$ & $77.53 \pm 0.02^{\mathrm{a}}$ & $17.99 \pm 0.04^{\mathrm{c}}$ & $85.52^{\mathrm{d}}$ \\
\hline
\end{tabular}

Means having the same superscript within columns are not significantly different at $P<0.05$.

A1 unfermented (1:1:1) AYB:SM:CM;

A2 unfermented (3:1:1) AYB:SM:CM;

A3 unfermented (5:1:1) AYB:SM:CM;

The total ash of the analogues ranged from 0.80 to $1.05 \%$ with sample A2 (unfermented 3:1:1) the lowest and sample B3 (fermented 5:1:1) the highest. The ash content of all samples ranged between 0.80 and $0.97 \%$ in unfermented samples and 0.89 to $1.05 \%$ in fermented samples. Makanjuola (2012) reported ash content of 0.50 to $0.60 \%$ for yoghurt from soy corn blend, these values were lower compared to observation in this study and this is likely due to differences in processing conditions and presence of higher level of suspended particles from AYB. The increase in the ash content is in contrast with the values of Muhammad et al. (2009) who reported ash content of 0.50 to $0.60 \%$ for yoghurt from soy corn blend, these values were lower compared to observation in this study which may be as a result of processing conditions and substrates.

The crude fibre contents of the milk analogues ranged from 0.17 to $0.34 \%$ with sample A2 (unfermented 3:1:1) having the lowest and sample B3 (fermented 5:1:1) having the highest. There was no significant difference $(\mathrm{p}>0.05)$ between samples A1 (unfermented 1:1:1) and B2 (fermented 3:1:1). Jacob et al.(2015) reported that consumption of fibre-rich foods lowers the level of cholesterol in
$B 1$ fermented(1:1:1) AYB:SM:CM;

B2 fermented (3:1:1) AYB:SM:CM;

B3 fermented (5:1:1) AYB:SM:CM

human blood and reduces the occurrence of different cancers. Carbohydrate content of milk analogues were in the range of 17.99 to $25.09 \%$, for fresh unfermented milk analogues 23.85 to $25.09 \%$ and for fermented yoghurt analogues 17.99 to $23.40 \%$. Carbohydrates are rich sources of carbon for microbial growth and thus; are metabolized by microbial cells resulting in reduction of these substrates in fermented milk. This also agrees with findings of Ebhodaghe et al. (2012) in stored probiotic soymilk. Fermentation possibly caused breakdown of carbohydrate to reducing sugars which in turn increased the sugar content of the milk. The sugar could be easily absorbed by the fermenting 'probiotic' organisms.

The moisture contents of the milk analogues ranged from 71.44 to $77.57 \%$ with sample B3 (fermented 5:1:1) having the highest and sample A2 (unfermented 3:1:1), the lowest as shown in Table 4.1. As the percentage of African yam bean increased, the moisture content increased. This agrees with the report of Mbaeyi (2011) who reported an increase in moisture content as the proportion of acha milk in the production cereallegume milk analogue. Fermentation increases the moisture content. 
The energy values ranged from $85.52 \mathrm{kcal} / 100 \mathrm{~g}$ to $113.91 \mathrm{kcal} / 100 \mathrm{~g}$ with sample B3 having the lowest value. The energy values all decreased with fermentation and increased proportion of AYB. The decrease may be due to the energy utilization by the microbes in this drink. The higher energy value of the samples was as a result of their higher protein and fat contents. The number of calories in a in a given food is termed energy value of the food; and is a good factor for comparing the true value of different foods.

\section{Physicochemical properties of the probioticated drinks}

The results of the physicochemical composition are presented in Table 2. The $\mathrm{pH}$ of the milk analogues ranged from 5.07 to 5.85 with sample A1 (unfermented milk blends AYB: SM: CM of ratio1:1:1) having the highest and sample $\mathrm{B} 3$ (fermented AYB: SM: CM of ratio 5:1:1) having the lowest. As the percentage of AYB increased, the $\mathrm{pH}$ decreased both in the fermented and unfermented milk analogues. It was observed that the $\mathrm{pH}$ of the fermented samples reduced and the reduction followed the trend with increase in the proportion of AYB. The activities of the probiotic organisms employed which led to the production of organic acids may be responsible for the decrease in $\mathrm{pH}$ as observed. Similar results were reported by Mbaeyi (2011).

Titratable acidity increased in all the samples after 24 hours of incubation. Initial titratable acidity for the unfermented milk analogues ranged from 0.12 to $0.21 \%$ LA with sample A3(5:1:1) having the highest and sample A1(1:1:1), the lowest while the titratable acidity for the fermented analogues ranged from 0.22 to $0.29 \%$ LA with sample B3 $(5: 1: 1)$ having the highest and sample B1 $(1: 1: 1)$, the lowest. The higher the proportion of $\mathrm{AYB}$, the higher the titratable acidity. The TTA followed similar trend with the $\mathrm{pH}$ of the samples. Titratable acidity of 0.13 to $0.80 \%$ LA was obtained from fermented milk blends from tigernut, soy and groundnut milk blends by Adeniran and Abiose (2011). Lower level of acids in these samples may be due to lower levels of fermentable sugars in the samples before fermentation. FAO (1986) states that the codex standard of titratable acidity as expressed as \% Lactic acid for fermented milks must be a minimal amount of $0.3 \%$. These samples did not meet this prescribed standard of titratable acidity.

The values of the total solids of the milk analogues ranged from 0.80 to $1.40 \%$ with sample A1 (unfermented 1:1:1) having the highest and sample B3 (fermented 5:1:1) the lowest. Sample A1 showed reduction from 1.40 to $1.00 \%$ after fermentation. Sample A2 (unfermented 3:1:1) also showed reduction from 1.20 to $1.00 \%$. The greatest reduction in total solids was observed in sample A3 (unfermented 5:1:1) which showed about 33\% reduction from 1.40 to $0.80 \%$. Fermentation could have been responsible for this reduction. Total solids reduced with higher proportion of AYB. The results obtained in this study were lower than the values (12.40 to14.5\%) reported by Osundahunsi et al. (2007) for soy yoghurt with fruits and Makanjuola (2012) who reported 8.80 to $10.98 \%$ total solid for soy-corn yoghurt. Total solid content is among the chemical characteristics that are overtly influenced by processing conditions like the method of hydrating the legume (beans), beans to water ratio and the extraction temperature (Mbaeyi, 2011).

The values of the total reducing sugars in all the samples ranged from 0.26 (sample B3) to 0.42 $\mathrm{mg} / \mathrm{ml}$ (sample A1). Coconut milk likely contributed to the reducing sugar content. The total reducing sugars generally reduced as the AYB content reduced as shown in (Table 2) for unfermented samples.

Table 2: Physicochemical Properties of the Milk Analogues

\begin{tabular}{lllll}
\hline Samples & pH & $\begin{array}{l}\text { TTA } \\
(\% \mathbf{L A})\end{array}$ & $\begin{array}{l}\text { Total Solids } \\
(\%)\end{array}$ & $\begin{array}{l}\text { Total Reducing } \\
\text { Sugars(mg/ml) }\end{array}$ \\
\hline A1 & $5.85 \pm 0.02^{\mathrm{a}}$ & $0.12 \pm 0.01^{\mathrm{c}}$ & $1.40 \pm 0.28^{\mathrm{a}}$ & $0.42 \pm 0.03^{\mathrm{a}}$ \\
\hline A2 & $5.66 \pm 0.01^{\mathrm{b}}$ & $0.18 \pm 0.01^{\mathrm{b}}$ & $1.20 \pm 0.57^{\mathrm{a}}$ & $0.34 \pm 0.07^{\mathrm{b}}$ \\
\hline A3 & $5.36 \pm 0.01^{\mathrm{c}}$ & $0.21 \pm 0.01^{\mathrm{b}}$ & $1.40 \pm 0.28^{\mathrm{a}}$ & $0.28 \pm 0.03^{\mathrm{c}}$ \\
\hline B1 & $5.29 \pm 0.00^{\mathrm{c}}$ & $0.22 \pm 0.01^{\mathrm{b}}$ & $1.00 \pm 0.28^{\mathrm{b}}$ & $0.39 \pm 0.17^{\mathrm{a}}$ \\
\hline B2 & $5.10 \pm 0.01^{\mathrm{d}}$ & $0.28 \pm 0.03^{\mathrm{a}}$ & $1.00 \pm 0.28^{\mathrm{b}}$ & $0.26 \pm 0.00^{\mathrm{c}}$ \\
\hline B3 & $5.07 \pm 0.02^{\mathrm{d}}$ & $0.29 \pm 0.06^{\mathrm{a}}$ & $0.80 \pm 0.00^{\mathrm{b}}$ & $0.27 \pm 0.00^{\mathrm{c}}$ \\
\hline
\end{tabular}

Means having the same superscript within columns are not significantly different at $P<0.05$.

A1 unfermented (1:1:1) AYB:SM:CM;

A2 unfermented (3:1:1) AYB:SM:CM; ;

A3 unfermented (5:1:1) AYB:SM:CM;
$B 1$ fermented (1:1:1) AYB:SM:CM;

B2 fermented(3:1:1) AYB:SM:CM;

$B 3$ fermented (5:1:1) AYB:SM:CM 
As more AYB meant reduction of coconut milk content. Fermentation also caused a reduction in the reducing sugars as the probiotic microorganisms could have utilized the available reducing sugars, a readily utilizable source of energy for microorganisms.

\section{Mineral composition of the probioticated drinks}

table 3 shows the results of the mineral composition of the assessed samples. The calcium content of all the analogues ranged from $5.97-9.46 \mathrm{mg} / 100 \mathrm{~g}$. The decrease in calcium content in the samples may be as a result of utilization of calcium present in the samples by the probiotic organisms employed. Calcium is responsible for the formation of strong bones and teeth. It is needed for growth as in the process of calcification for animals. It also helps in blood clotting when an injury is sustained. It also helps in the proper functioning of nerves. When there is a limited supply calcium to the body, the body extracts the needed calcium from the bones. If there is continuous extraction of calcium from the bones, a condition, osteoporosis occurs. The bones will become weak and brittle (Aliyu et al., 2008; Jacob et al., 2015). The calcium content of the milk analogues decreased with fermentation and increase in the proportion of AYB. Iron contents in the analogues ranged from 10.27 to $13.26 \mathrm{mg} / 100 \mathrm{~g}$. There was significant difference at $5 \%$ level of iron in all the analogues. Iron showed an exception to this trend as it increased with fermentation. Iron is essential in in human nutrition to prevent anaemia. Iron helps in the formation of blood and in cellular respiration (Jacob et al., 2015). Iron deficiency results in retarded brain functionality and behavioural problems in children (McDonald et al., 1995). There was also a reduction in the zinc content of the milk analogues. Zinc boosts the growth of the hairs, important in the proper functioning of sensory ability such as taste and smell (Payne, 1990; Jacob et al., 2015), helps in carbohydrate, protein and vitamin A metabolism from its storage site in the livers. It enhances the synthesis of DNA and RNA necessary for cell production (Jacob et al., 2015).

All the milk analogues contained a considerable amount of potassium. It ranged from 74.48 to $90.34 \mathrm{mg} / 100 \mathrm{~g}$. This is the most abundant of the entire element determined in these samples. High concentration of potassium in the body as reported by Adeyeye (2002) increases iron utilization and benefits diuretic patients to control hypertension and prevent excessive excretion of potassium through the body fluid (Arinanthan et al., 2003). Potassium is available in several foods including dairy products and its recommended daily allowance is $3500 \mathrm{mg}$. The sodium content of the analogues ranged from 5.37 to $6.87 \mathrm{mg} / 100 \mathrm{~g}$. Sodium regulates homeostasis in the body and helps in the effective functioning of muscles and nerves (Payne, 2012). The Institute of Medicine, Food and Nutrition Board recommended sodium daily allowance of $2400 \mathrm{mg}$ for adults and children aged 4 and older for sodium is (Jacob et al., 2012).

$\mathrm{Na} / \mathrm{K}$ plays a very crucial role in controlling high blood pressure in the body. Studies showed that lower sodium and higher potassium intake helps in the reduction of high blood pressure in hypertensive patients. The recommended $\mathrm{Na} / \mathrm{K}$ ratio should be less than one. The $\mathrm{Na} / \mathrm{K}$ ratio value of 0.07 to 0.08 was obtained for the milk analogues. The report of this finding showed that regular consumption of this fermented milk analogue could help to prevent hypertension. This result is in concord with the findings of Aremu et al. (2006); Jacob et al. (2015) who reported that Nigerian legumes that are underutilised are good means of diets for lowering blood pressure. Higher $\mathrm{Ca} / \mathrm{K}$ levels in foods are necssary for favourable calcium formation (Nieman et al., 1992; Jacob et al., 2015).

\section{Antinutrients of the AYB-based probiotic drink}

The results obtained for the antinutrients of AYB based drinks is presented in Table 4 . The phytate contents of the milk analogues ranged from 2.85 to $4.07 \mathrm{mg} / 100 \mathrm{~g}$. Sample A3 (unfermented 5:1:1 milk analogue) had the highest and sample B1 (fermented 1:1:1 milk analogue) had the lowest value. It was noted that as the proportion of AYB milk increased, the phytate content also increased. There were significant differences $(\mathrm{p}<0.05)$ among the samples. The values obtained are within safe limits. Phytate reduces calcium bioavailability and forms calcium phytate complexes that prevents the absorption of iron. It is dependent on the crop variety, climatic conditions, location, irrigation conditions, type of soil, and the growing season of the plant (Plaami, 1997).

The oxalates content of the analogues ranged between 1.26 and $1.65 \mathrm{mg} / 100 \mathrm{~g}$. Sample B1 (fermented 1:1:1 milk analogue) had the lowest while sample A3 (unfermented 5:1:1 milk analogue) had the highest value. These values are lower than the daily recommended value. 
Table 3: Mineral Contents of the Milk Analogues (mg/100g)

\begin{tabular}{lllllll}
\hline Samples & Ca & Fe & Zn & K & Na & Na/K ratio \\
\hline A1 & $9.64 \pm 0.02^{\mathrm{a}}$ & $10.26 \pm 0.00^{\mathrm{c}}$ & $5.59 \pm 0.00^{\mathrm{b}}$ & $88.84 \pm 0.03^{\mathrm{a}}$ & $6.67 \pm 0.01^{\mathrm{a}}$ & 0.07 \\
\hline $\mathrm{A} 2$ & $8.85 \pm 0.00^{\mathrm{b}}$ & $11.17 \pm 0.03^{\mathrm{bc}}$ & $6.36 \pm 0.01^{\mathrm{a}}$ & $90.34 \pm 0.01^{\mathrm{a}}$ & $6.87 \pm 0.01^{\mathrm{a}}$ & 0.08 \\
\hline A3 & $7.47 \pm 0.01^{\mathrm{c}}$ & $12.36 \pm 0.01^{\mathrm{b}}$ & $5.48 \pm 0.01^{\mathrm{b}}$ & $85.27 \pm 0.03^{\mathrm{b}}$ & $5.97 \pm 0.00^{\mathrm{b}}$ & 0.07 \\
\hline B1 & $8.37 \pm 0.02^{\mathrm{b}}$ & $10.69 \pm 0.00^{\mathrm{c}}$ & $4.87 \pm 0.01^{\mathrm{c}}$ & $80.13 \pm 0.00^{\mathrm{c}}$ & $6.77 \pm 0.00^{\mathrm{a}}$ & 0.08 \\
\hline B2 & $6.12 \pm 0.00^{\mathrm{d}}$ & $12.45 \pm 0.01^{\mathrm{b}}$ & $6.67 \pm 0.00^{\mathrm{a}}$ & $77.77 \pm 0.03^{\mathrm{c}}$ & $5.37 \pm 0.02^{\mathrm{b}}$ & 0.07 \\
\hline B3 & $5.97 \pm 0.00^{\mathrm{d}}$ & $13.26 \pm 0.00^{\mathrm{a}}$ & $4.74 \pm 0.01^{\mathrm{c}}$ & $74.48 \pm 0.02^{\mathrm{c}}$ & $5.45 \pm 0.01^{\mathrm{b}}$ & 0.07 \\
\hline
\end{tabular}

Means having the same superscript within columns are not significantly different at $P<0.05$

A1 unfermented $(1: 1: 1)$ AYB:SM:CM

$B 1$ fermented (1:1:1) AYB:SM:CM

A2 unfermented (3:1:1) AYB:SM:CM

B2 fermented(3:1:1) AYB:SM:CM

A3 unfermented (5:1:1) AYB:SM:CM

$B 3$ fermented (5:1:1) AYB:SM:CM

Table 4: Antinutrients of the Milk Analogues (mg/100g)

\begin{tabular}{lllll}
\hline Samples & Phytate & Tannin & Saponin & Oxalates \\
\hline A1 & $3.67 \pm 0.00^{\mathrm{b}}$ & $2.65 \pm 0.01^{\mathrm{b}}$ & $0.24 \pm 0.01^{\mathrm{b}}$ & $1.43 \pm 0.01^{\mathrm{b}}$ \\
\hline A2 & $3.76 \pm 0.01^{\mathrm{b}}$ & $2.76 \pm 0.00^{\mathrm{a}}$ & $0.28 \pm 0.00^{\mathrm{a}}$ & $1.64 \pm 0.01^{\mathrm{a}}$ \\
\hline A3 & $4.07 \pm 0.03^{\mathrm{a}}$ & $2.86 \pm 0.03^{\mathrm{a}}$ & $0.32 \pm 0.01^{\mathrm{a}}$ & $1.65 \pm 0.02^{\mathrm{a}}$ \\
\hline B1 & $2.85 \pm 0.01^{\mathrm{d}}$ & $2.27 \pm 0.03^{\mathrm{c}}$ & $0.19 \pm 0.00^{\mathrm{c}}$ & $1.26 \pm 0.00^{\mathrm{c}}$ \\
\hline B2 & $3.36 \pm 0.01^{\mathrm{bc}}$ & $2.49 \pm 0.00^{\mathrm{bc}}$ & $0.25 \pm 0.00^{\mathrm{b}}$ & $1.29 \pm 0.00^{\mathrm{c}}$ \\
\hline B3 & $3.59 \pm 0.00^{\mathrm{b}}$ & $2.56 \pm 0.01^{\mathrm{b}}$ & $0.25 \pm 0.00^{\mathrm{b}}$ & $1.39 \pm 0.00^{\mathrm{b}}$ \\
\hline
\end{tabular}

Means having the same superscript within columns are not significantly different at $P<0.05$

A1 unfermented $(1: 1: 1)$ AYB:SM:CM

A2 unfermented (3:1:1) AYB:SM:CM

A3 unfermented (5:1:1) AYB:SM:CM

Aburime (2012) reported that lethal dose of oxalate is between $200 \mathrm{mg} / 100 \mathrm{~g}$ and $500 \mathrm{mg} / 100 \mathrm{~g}$.

The saponin contents ranged from 0.19 to 0.32 $\mathrm{mg} / 100 \mathrm{~g}$. Sample B1 (fermented 1:1:1 milk analogue) had the lowest while sample A3 (unfermented 5:1:1 milk analogue) had the highest. As the proportion of AYB increased, the saponin content also increased. The values obtained for study are considerably lower than the allowable value.

The range of the tannin content was between 2.27 and $2.86 \mathrm{mg} / 100 \mathrm{~g}$ for the milk analogues. Sample B1 (fermented 1:1:1 milk analogue) had the lowest and sample A3 (unfermented 5:1:1 milk analogue) had the highest. The total acceptable tannin daily intake for a man is $560 \mathrm{mg}$ (Stephane, 2004; Habtamu and Negussie, 2014). From the results obtained in this study, the concentrations of oxalate, tannin, phytate and saponin in these probioticated drinks are too low to constitute any health risk in human being.

\section{Sensory properties of the probioticated drinks}

The result of the sensory charcteristics is shown in Table 5. The milk analogues with equal proportions of AYB, coconut and soymilk (samples A1 and B1) were scored by the tasters as the best in terms of colour. The percentage of coconut milk and soymilk could have been responsible for the milky colour which masked the brown colour possessed by the AYB milk. Adelodun and Abiodun (2012) also reported an acceptable colour from blends of soy-
$B 1$ fermented $(1: 1: 1)$ AYB:SM:CM

B2 fermented(3:1:1) AYB:SM:CM

B3 fermented(5:1:1) AYB:SM:CM coconut milk-based yoghurt. The appearance of the yoghurt determines to the level of visual appeal of the products obtained by fermenting the various milk substrates with relevant microbes (Sanful, 2009). Colour is an vital determinant of many foods including yoghurt and yoghurt analogue. It is a quality attributes that with flavour and texture play an important role in food acceptability. According to Ihekoronye and Ngoddy (1985) and Mbaeyi (2011), colour is defined as a interpretation of a physiological response by the brain and eye to the physical stimulus of light radiation at different wavelength.

The most preferred sample in terms of aroma was sample B1 (fermented AYB:SM:CM 1:1:1). This was followed by sample A1 (unfermented AYB:SM:CM 1:1:1). Higher proportion of coconut milk and the process of fermentation could be responsible for the flavour imparted on sample B1. Lactic acid fermentation is a means of reducing beany flavours and antinutritional factors in soy products. Sample A3 (unfermented 5:1:1 milk analogue) was least preferred by the panelists. Presence of sugars in milk blends contributed by the coconut milk may have been responsible for the significant difference. Soybean and African yam bean milk extracts have beany flavour; this might have imparted negatively on the choice of milk from legumes but addition of coconut into the milk extracts likely imparted a flavour that masked beany 
flavour. Flavour is a strong quality factor that determine beverage acceptability compared to other qualities (Gaffa and Ayo, 2003).

Yoghurt is enjoyed because of its tart acidic taste and flavour (Alakali et al., 2008). Sample B1 (fermented AYB:SM:CM 1:1:1) had the best taste as scored by the panelists. The effect of acidity on the starch (from the African yam milk extract) may not be ruled out. Also, the higher sugar content from coconut milk in sample B1 could have resulted in the manufacture of organic acids. The percentage of coconut milk might have imparted a pleasant taste to the sample. Fermentation confers new and desirable tastes and textures that are completely different from those present in the starting materials.

Mouthfeel/consistency quality of the yoghurt refers to the property of the yoghurt which indicates the smoothness and good flow properties (Sanful,2009). The acceptance of the products means that the solubility of the solids from the combined substrates must have been improved upon by fermentation as compared in the samples. It was also evident that the effectiveness of mixing of the various substrates after fermentation was appreciated. Sample B1 (fermented 1:1:1 milk analogue) has the best mouthfeel as it was homogenous and the flow was good and consistent. There was no separation between the particles of the molecules in sample B1. Samples A3, B1 and B3 were preferred among all the samples. Sample A2 (unfermented 3:1:1 milk analogue) was the least accepted. This was probably due to the lactic acid produced which gave the samples the desirable tart taste and viscosity in yoghurt. Acceptability of the milk extracts agrees with the reports of Agunbiade et al. (2011) who indicated that milk from soybean, Bambara groundnut and African yam bean compared favourably with dairy milk. Also, Udeozor (2012) reported acceptability of equal proportion of blends of tigernut, soy and groundnut milk. Adeniran and Abiose (2011) reported acceptability of milk blends from plant sources (tigernut, soy and groundnut milk). It was encouraging to note that although the fermented products had varied scores, they were still acceptable to the panelists probably because sour gruels and beverages/ drinks are common in local food preferences. According to Fellows (1997) and Abou-Dobara (2016) the main quality factors for yoghurt are the colour (appearance), taste and texture (mouthfeel). All the vegetable milk analogues evaluated were moderately liked by the panelists with respect to all the attributes for yoghurt. The sourness of the yoghurt expresses the level of astringency produced by lactic acid by the action of Lactobacillus delbrueckii on lactose in the substrate. Also, the aroma produced from the fermentation of the yoghurt is particularly due to acetaldehyde formation and other volatile aromatic compounds resulting from the anaerobic breakdown of carbohydrates by these beneficial microbes (Sanful, 2009; Mbaeyi, 2011).

Table 5: Sensory Evaluation of the Milk Analogues Produced from Blends of AYB, Soybean and Coconut

\begin{tabular}{llllll}
\hline Samples & Colour & Mouthfeel & Taste & Flavour & $\begin{array}{c}\text { Overall } \\
\text { acceptability }\end{array}$ \\
\hline A1 & $2.5 \pm 0.53^{\mathrm{a}}$ & $1.2 \pm 0.03^{\mathrm{d}}$ & $2.1 \pm 0.74^{\mathrm{b}}$ & $2.4 \pm 0.27^{\mathrm{a}}$ & $1.8 \pm 0.33^{\mathrm{b}}$ \\
\hline $\mathbf{A 2}$ & $2.2 \pm 0.25^{\mathrm{c}}$ & $1.5 \pm 0.85^{\mathrm{c}}$ & $1.4 \pm 0.84^{\mathrm{c}}$ & $1.4 \pm 0.84^{\mathrm{c}}$ & $2.2 \pm 0.29^{\mathrm{b}}$ \\
\hline $\mathbf{A 3}$ & $2.2 \pm 0.25^{\mathrm{b}}$ & $2.6 \pm 0.23^{\mathrm{b}}$ & $2.4 \pm 0.22^{\mathrm{b}}$ & $2.1 \pm 0.74^{\mathrm{b}}$ & $2.4 \pm 0.70^{\mathrm{a}}$ \\
\hline B1 & $2.5 \pm 0.53^{\mathrm{a}}$ & $3.0 \pm 0.93^{\mathrm{a}}$ & $4.3 \pm 1.98^{\mathrm{a}}$ & $2.5 \pm 0.53^{\mathrm{a}}$ & $2.4 \pm 0.22^{\mathrm{a}}$ \\
\hline B2 & $1.7 \pm 0.53^{\mathrm{c}}$ & $1.9 \pm 0.52^{\mathrm{cd}}$ & $1.7 \pm 0.30^{\mathrm{c}}$ & $2.2 \pm 0.25^{\mathrm{b}}$ & $2.0 \pm 0.21^{\mathrm{ab}}$ \\
\hline B3 & $1.0 \pm 0.00^{\mathrm{d}}$ & $2.3 \pm 0.67^{\mathrm{c}}$ & $2.3 \pm 0.67^{\mathrm{b}}$ & $1.6 \pm 0.22^{\mathrm{c}}$ & $2.2 \pm 0.70^{\mathrm{a}}$ \\
\hline
\end{tabular}

Means having the same superscript within columns are not significantly different at $P<0.05$

A1 unfermented (1:1:1) AYB:SM:CM

B1 fermented(1:1:1) AYB:SM:CM

A2 unfermented (3:1:1) AYB:SM:CM

$B 2$ fermented(3:1:1) AYB:SM:CM

A3 unfermented (5:1:1) AYB:SM:CM

B3 fermented(5:1:1) AYB:SM:CM

\section{CONCLUSIONS}

The study produced probioticated drinks from various blends of milk analogues from AYB, soybean and coconut. The study concluded that increase in the proportion of AYB produced analogues of high acidity, low $\mathrm{pH}$, high protein, high potassium, energy and acceptable sensory qualities. Sample with equal ratio was the most acceptable of all samples.

\section{ACKNOWLEDGMENT}

The authors are grateful to the Department of Food Science and Technology for the assistance rendered during the study. 


\section{REFERENCES}

1. Abou-Dobara, Mohamed Ismail, Magdy Mohamed Ismail, Nawal Mohamed Refat, Chemical Composition, Sensory Evaluation and Starter Activity in Cow, Soy, Peanut and Rice Milk, American Journal of Chemical Engineering. Vol. 4, No. 6, 2016, pp. 179-186. doi: 10.11648/j.ajche.20160406.16.

2. Aguolar, Edilberto Flores and Emille del Pilar Flores Rovera (2019). Assessment of the use of the hydrolyzed liquid fraction of the kiwicha grain in the fermentation process of probiotic drinks from tarwi juice: microbiological, chemical and sensorial analysis, Food Science and Technology, Campinas, 39(3): $592-598$

3. Adelodun, L. K. and Abiodun, O. O. (2012). Effect of different concentrations of coconut milk on the chemical and sensory properties of soy-coconut milk-based yoghurt. Food and Public Health, 2(4): 8591.

4. Adeniran, H. A. and Abiose, S. H. (2011). Characterization and hydrolytic activities of amylases from Bacillus licheniformis and Aspergillus niger cultivated on agricultural residues. African Journal of Biotechnology, 11(6): 1465-1477.

5. Adeniran, H. A., Olaniyi, O. A. and Abiose, S. H. (2015). Viability and effect of probiotic lactic acid bacteria isolated from locally fermented foods in a non-dairy beverage from African yam bean. Proceedings of the OAU Faculty of Technology Conference, 71-78.

6. Adeyeye, E. I.(2002). Determination of chemical composition of the nutritionally valuable parts of male and female common West African fresh water crab (Sudananoutes africanus). Food Chemistry, 28-30.

7. Agunbiade, S. O., Amosu, A. M., Mand, D. A. and Omeonu, P. E.(2011). The physicochemical and organoleptic properties of milk fabricated from Glycine max, Vigna subterranean and Sphenostylis stenocarpa. Journal of Chemical and Pharmaceutical Research, 3(6): 918-924.

8. Akoma, O., Musa, S., Akoma, A. O. and Asunmo, R. G. (2005). Nutritional values of yoghurt produced with locally developed starter culture isolated from nono. Proceedings of the 29th NIFST AGM/Conference, Ebonyi State University, Abakaliki, 11th-13th October, 5: 292-293, 2005.

9. Alakali, J. S., Okonkwo, T. M and Iordye, E. M. (2008). Effect of stabilizers on the physico-chemical and sensory attributes of thermized yoghurt. African Journal of Biotechnology, 7(2): 158-163.

10. Aliyu, A. B., Musa, A. M. and Oshaniyi, J. A.(2008). Phytochemical analysis and mineral composition analysis of some medicinal plants of Northern Nigeria. Nigerian Journal of Pharmaceutical Sciences, 7(1): 119-121.

11. Amakoromo, E. R., Innocent-Adiele, H. C. and Njoku, H. O.(2012). Physicochemical quality of a yoghurt-like product from African yam bean. Report Opinion, 4(4): 58-61.

12. Aminigo, E. R., Lehtola, P. S. and Metzger, L. E.(2007). Nutritive composition and physical characteristics of supplemented imitation milk from African yam bean (Sphenostylis stenocarpa). Global Journal of Pure and Applied Sciences, 13: 457-462.

13. Arinanthan, V., Mohan, V. R. and Britto, A. J.(2003). Chemical composition of certain tribal pulses in South India. International Journal of Food Sciences and Nutrition, 3: 103-107.

14. Association of Official Analytical Chemists (AOAC) (1990). Official Methods of Analysis. $15^{\text {th }}$ edition Washington, DC: Association of Official Analytical Chemists.

15. Brunner, J. H. (1984). Direct spectrophometric determination of saponin. Annals of Chemistry, 42: 17521754.

16. Ebhodaghe, S. O., Abiose, S. H. and Adeniran, H. A. (2012). Assessment of physico-chemical characteristics, viability and inhibitory effect of Bifidobacteria in soymilk. Journal of Food Research, 1(2): 159-169.

17. Edilberto Flores Aguolar and Emille del Pilar Flores Rovera (2019). Assessment of the use of the hydrolyzed liquid fraction of the kiwicha grain in the fermentation process of probiotic drinks from tarwi juice: microbiological, chemical and sensorial analysis, Food Science and Technology, Campinas, 39(3): $592-598$

18. FAO. (1986). Composition Analytical Methods. In: Manuals of Food Quality Control. Food and Agricultural Organization of the United Nations, Rome, Pp 204-230.

19. Fellows, P. (1997). Traditional Foods Processing for Profit. 1st edition, Intermediate Technology Publisher Limited, London.

20. Folasade, M. and Oyenike, O.(2012). Effect of sesame seed addition on the chemical and sensory qualities of sorghum based kunun-zaki drink. African Journal of Food Science and Technology, 3(9): 204-212. 
21. Gaffa, T. and Ayo, J. A.(2012). Physiochemical and sensory effects of Cadaba farinosa crude extract on cereal starches during kunun-zaki production. Pakistan Journal of Nutrition, 2(1): 13-17.

22. Habtamu, F. G. and Negussie, R.(2014). Antinutritional factors in plant foods: potential health benefits and adverse effects. Global Advanced Research Journal of Food Science and Technology, 3(4): 103-117.

23. Hassan, A. M., Abdallah, M. I. M, Bazalou, M. S. and Abo-Samra, R. G.(2013). Effect of probiotics bacteria isolated from yoghurts produced in Damietta city on some pathogenic bacteria. Proceedings of the 6th Animal Wealth Research Conference in the Middle East and North Africa Hurghada information center- 27-30, 01-14, September.

24. Ihekoronye, A. I. and Ngoddy, P. O.(1985). Integrated Food Science and Technology for Tropics, London, UK, Pp 1-386.

25. Jacob, A. G., Etong, D. I. and Tijani, A.(2005). Proximate, mineral and anti-nutritional factors in tigernut, soyabean and coconut milk sources. International Journal of Agriculture and Biology, 9(5), 785 -787.

26. Larmond, E., Laboratory methods for sensory evaluation of foods. Canadian Agricultural publications. Series IV, Ottawa. Canada.

27. Lukas, C. S. and Makarkas, P.(1975). Phytic acid and other phosphorus compounds of bean (Phaseolus vulgaris). Journal of Agricultural Education and Chemistry, 23: 13-15.

28. Madhavi, Tellabati V.T. Rajasekhar and R.K. Shah (2018) Physico:Chemical analysis of Probiotic/Synbiotic whey drink with orange juice. International Journal of Chemical Studies, 6(2): 26892694.

29. Makanjuola, O. M.(2012). Production and quality evaluation of soy-corn yoghurt. Advanced Journal of Food Science and Technology, 4(3): 130-134.

30. Makkar, H. P., Blummel, M. and Becken, K.(1993). Determination of tannin and its correlation with chemical and protein precipitation method. Journal of Science, food and Agriculture, 6: 161-165.

31. Mbaeyi, I. E.(2011). Studies on cereal-legume blend potential for development of novel non-dairy probiotic yoghurt analogues. Ph. D submitted to the Department of Microbiology, University of Nigeria, Nsukka.

32. McDonald, A., Edwards, R. A., Greenhulgh, F. D. and Morgan, C. A. (1995). Animal Nutrition. Prentices Hall, London, Pp 101-122.

33. Muhammad, B. F., Abubakar, M. M. and Adegbola, T. A. (2009). Effect of period and condition of storage on properties of yoghurt produced from cow milk and soymilk materials. Research Journal of Dairy Science, 2: $18-24$.

34. Nieman, D. C., Butterworth, D. E and Nieman, C. N. (1992). Nutrition watch, WMC Brown Publishers, Dubugye, USA.

35. Oke, O. L. (1969). The role of hydrocyanide acid in nutrition. World review of Nutrition and Dietetics, 11: 118-147.

36. Osundahunsi, O. F., Amosu, D., Ifesan, B. O. T. (2007). Quality evaluation and acceptability of soyyoghurt with different colours and fruit flavours. American Journal of Food Technology, 2: 273-280.

37. Payne, W. J. A.(1990) An Introduction to Animal Husbandry in the Tropics. Longman Publishers, Singapore, 92- 110.

38. Plaami, S. (1997). Myoinositol phosphates: Analysis, content in foods and effects in nutrition. British Microbiology Research Journal, 3(2): 198-205.

39. Sanful, R. E. (2009). The use of tigernut (Cyperus esculentus), cow milk and their composite as substrates for yoghurt production. Pakistan Journal of Nutrition, 8(6): 755-758.

40. Soccol, C. R., Vandernberghe, L. P., Spier, M. R., Medeiros, A. B. P, Yamaguishi, C. T, Lindner, J. D, Pandey, A. and Thomaz-Soccol, V. (2010). The potential of probiotics. Food Technology and Biotechnology, 48(4): 413-434.

41. Stéphane, R. (2004). Interaction of grape seed procyanidins with various proteins in relation to wine fining. Journal of Science Food Agriculture, 57: 111-125.

42. Udeozor, L. O. (2012). Tigernut-soy milk drink: preparation, proximate composition and sensory qualities. International Journal of Food and Nutrition Science, 1(4): 18-26.

43. Yilmaz-Ersan, L and Kurdal, E.(2014). The production of set-type-bio-yoghurt with commercial probiotic culture. International Journal of Chemical Engineering and Applications, 5(5): 402:408. 